\title{
A SEROTYPING SYSTEM FOR CLOSTRIDIUM WELCHII (C. PERFRINGENS) TYPE A, AND STUDIES ON THE TYPE-SPECIFIC ANTIGENS
}

\author{
Jane A. Hughes*, P. C. B. Turndull and M. F. Stringer \\ Food Hygiene Laboratory, Central Public Health Laboratory, Colindale NW9 5 HT
}

Clostridium welchil ( $C$. perfringens) type $\mathrm{A}$ is now firmly established as an important cause of food poisoning in Britain and throughout the world. Between 1969 and 1974, it was responsible for 200 reported general outbreaks of food poisoning (20.4\% of all general outbreaks) in England and Wales in which 8881 persons were affected $(18.5 \%$ of all food poisoning; Vernon and Tillett, 1974; Vernon, personal communication).

Type-specific antisera were first prepared by Hobbs et al. (1953) against heat-resistant strains of $C$. welchii isolated from foods incriminated in foodpoisoning outbreaks. The number of sera in use was increased markedly after it had been established that the more heat-sensitive classical strains were also responsible for C. welchii food poisoning (Hall et al., 1963; Taylor and Coetzee, 1966; Sutton and Hobbs, 1968). By 1973, 48 antisera were available for determining possible relationships between food and faecal isolates of $C$. welchii, and the set comprised 57 antisera by the end of 1975 .

This paper describes the application of the serotyping scheme to the investigation of 153 outbreaks of suspected $C$. welchii food poisoning over the 3-year period 1973-75. Results of related epidemiological studies and studies on the location of the strain-specific antigen are also presented.

\section{MATERIALS AND METHODS}

Preparation of antisera. Antisera were prepared by the method of Henderson (1940). The cells were grown in $1 \%$ Glucose Broth (Oxoid), washed twice, and re-suspended in $0.4 \mathrm{ml}$ of formalin in $100 \mathrm{ml} 0.85 \%$ saline to give a concentration of $2 \times 10^{10}$ cells per ml as determined with Brown's opacity tubes. A 2-week course of intravenous injections in rabbits consisted of six doses $(0 \cdot 1,0 \cdot 2,0 \cdot 4,0 \cdot 8,1 \cdot 0$ and $1.0 \mathrm{ml})$ administered at 3-day intervals; this usually gave a serum with a titre of 800-6400. Details of the sources of the 57 serotypes at present comprising the serotyping scheme are given in table I. All but one of the strains were isolated from food or faecal samples examined in connexion with outbreaks of food poisoning.

Serotyping of strains. Strains of $C$. welchii mostly in cooked-meat medium were submitted for serotyping by public health laboratories and hospital pathology departments throughout Great Britain. Full information about the outbreaks was obtained when possible by the use

Received 23 Jan. 1976; revised version accepted 15 Apr. 1976.

* Present address: Madadeni Hospital, Newcastle, Natal 2940, South Africa. Reprint requests to P. C. B. T.

J. MED. MICROBIOL.-VOL. 9 (1976) 


\section{TABLE I}

Details of strains used for the preparation of antisera to Clostridium welchii type A developed in the Food Hygiene Laboratory

\begin{tabular}{|c|c|c|c|c|c|c|c|}
\hline $\begin{array}{c}\text { Serotype } \\
\text { no. }\end{array}$ & $\begin{array}{c}\text { Culture reference } \\
\text { no. }\end{array}$ & \multicolumn{2}{|l|}{$\begin{array}{c}\text { Source } \\
\text { and history* }\end{array}$} & $\begin{array}{c}\text { Serotype } \\
\text { no. }\end{array}$ & $\begin{array}{c}\text { Culture reference } \\
\text { no. }\end{array}$ & \multicolumn{2}{|l|}{$\begin{array}{c}\text { Source } \\
\text { and history* }\end{array}$} \\
\hline 1 & NCTC8797 & Boiled salt beef & $\mathrm{C}$ & 30 & FH3794/67 & Tongue & $\mathrm{NC}$ \\
\hline 2 & NCTC 8238 & Boiled salt beef & $\mathrm{C}$ & 31 & FH3853/67 & Tongue & PC \\
\hline 3 & NCTC 8239 & Boiled salt beef & $\mathrm{C}$ & 32 & FH3911/73 & Faeces & $\mathrm{C}$ \\
\hline 4 & NCTC8247 & Meat pasty & $\mathrm{C}$ & 33 & FH4436/73 & Tongue & $\mathrm{C}$ \\
\hline 5 & NCTC 8678 & Faeces & $\mathrm{C}$ & 34 & FH5337/73 & Minced beef & $\mathrm{C}$ \\
\hline 6 & NCTC 8679 & Faeces & $\mathrm{C}$ & 35 & FH50/72 & Blancmange & $\mathrm{NC}$ \\
\hline 7 & NCTC 8449 & Stewed lamb & $\mathrm{C}$ & 36 & FH4552/72 & Turkey & $\mathrm{NC}$ \\
\hline 8 & NCTC8235 & Stew & $\mathrm{C}$ & 37 & FH10209/66 & Faeces & $\mathrm{C}$ \\
\hline 9 & NCTC8798 & Rissole & $\mathrm{C}$ & 38 & FH1073/67 & Roast pork & PC \\
\hline 10 & NCTC8799 & Roast meat & C & 39 & FH9222/67 & Brisket & $\mathrm{C}$ \\
\hline 11 & NCTC 9851 & Braised heart & $\mathrm{C}$ & 40 & FH2932/67 & Roast beef & $\mathrm{C}$ \\
\hline 12 & NCTC 10239 & Faeces & $\mathrm{C}$ & 41 & FH3663/73 & Pork & $\mathrm{C}$ \\
\hline 13 & NCTC 10240 & Chicken & $\mathrm{C}$ & 42 & $\mathrm{FH} 2925 / 74$ & Faeces & $\mathrm{NC}$ \\
\hline 14 & NCTC10611 & Faeces & $\mathrm{C}$ & 43 & FH1922/74 & Semolina & $\mathrm{C}$ \\
\hline 15 & NCTC10613 & Mincemeat & $\mathrm{C}$ & 44 & FH2889/74 & Beef & $\mathrm{C}$ \\
\hline 16 & NCTC10614 & Faeces & $\mathrm{C}$ & 45 & FH2890/74 & Beef & $\mathrm{C}$ \\
\hline 17 & FH6849/67 & Faeces & $\mathrm{C}$ & 46 & $\mathrm{FH} 1774 / 74$ & Gravy & $\mathrm{NC}$ \\
\hline 18 & FH10486/67 & Faeces & $\mathrm{C}$ & 47 & FH1185/74 & Faeces & $\mathrm{NC}$ \\
\hline 19 & FH1149/67 & Faeces & $\mathrm{C}$ & 48 & FH3158A/74 & Faeces & $\mathrm{C}$ \\
\hline 20 & FH3483/68 & Faeces & $\mathrm{C}$ & 49 & FH3158B/74 & Faeces & $\mathrm{C}$ \\
\hline 21 & FH3746/68 & Faeces & $\mathrm{C}$ & 50 & FH3565/74 & Faeces & NC \\
\hline 22 & FH3858/68 & Minced kidney & $\mathrm{C}$ & 51 & FH3579/74 & Faeces & $\mathrm{NC}$ \\
\hline 23 & FH7869/66 & Faeces & $\mathrm{NC}$ & 52 & FH3799/74 & Faeces & $\mathrm{NC}$ \\
\hline 24 & FH7870/66 & Faeces & $\mathrm{C}$ & $5 \overline{3}$ & FH4137/74 & Lesion of & $\mathrm{C}$ \\
\hline 25 & FH4062/70† & Cream doughnut & $\mathrm{NC}$ & & & necrotic enteritis & $\mathrm{C}$ \\
\hline 26 & FH1086/67 & Roast pork & PC & 54 & FH4314/74 & Faeces & $\mathrm{C}$ \\
\hline 27 & FH7871/66 & Faeces & $\mathrm{NC}$ & 55 & FH4930/74 & Chicken pie & $\mathrm{C}$ \\
\hline 28 & FH1543/67 & Mincemeat & $\mathrm{C}$ & 56 & FH5049/74 & Faeces & $\mathrm{NC}$ \\
\hline 29 & FH1539/68 & Faeces & $\mathrm{C}$ & 57 & FH5069/74 & Faeces & $\mathrm{NC}$ \\
\hline
\end{tabular}

${ }^{*} \mathrm{C}=$ causative of outbreak, i.e., isolated from food or the majority of faeces associated with the outbreak or both; $\mathrm{NC}=$ not causative of outbreak; $\mathrm{PC}=$ probably causative; evidence insufficient for definite inference.

$\dagger=$ This strain replaces the original strain used to prepare the serum.

of a questionnaire. On a number of occasions, counts of $C$. welchii in the food and faecal samples were done by the laboratories investigating the outbreaks and receiving the specimens; the methods used were those described by Sutton, Ghosh and Hobbs (1971). Isolates of $C$. welchii from these laboratories were plated on horse-blood agar that had been spread with three drops of a $1 \%$ neomycin solution and incubated anaerobically at $37^{\circ} \mathrm{C}$ overnight. The blood agar was made up of a base layer of peptone water agar and a top layer of nutrient agar (Oxoid Nutrient Broth no. 2 with 1\% Davis New Zealand Agar) containing 5\% defibrinated horse blood (Burroughs Wellcome). Haemolysis and colony form were noted, bacterial morphology was checked by Gram's stain, and colonies were picked to plates of eggyolk agar formulated according to the method of McClung and Toabe (1947). The strains were serotyped from the blood agar or egg-yolk plates by slide-agglutination tests.

Determination of the strain-specific antigen. To demonstrate the presence of capsules, smears of the cells were suspended in Indian ink, dried in air, stained with $1 \%$ carbol fuchsin for $1 \mathrm{~min}$. and re-dried for microscopic inspection.

The relationship of the strain-specific antigen to the capsule was studied by means of the 
TABLE II

Application of the Clostridium welchii type A serotyping system to the investigation of food-poisoning outbreaks

\begin{tabular}{|c|c|c|c|c|}
\hline \multicolumn{3}{|c|}{ Food-poisoning outbreaks } & & \\
\hline \multirow[t]{2}{*}{$\begin{array}{l}\text { Year of } \\
\text { occurrence }\end{array}$} & \multirow[t]{2}{*}{$\begin{array}{l}\text { Number } \\
\text { investigated }\end{array}$} & \multirow{2}{*}{$\begin{array}{l}\text { Number (and } \\
\text { percentage) } \\
\text { in which the } \\
\text { causative } \\
\text { serotype was } \\
\text { determined }\end{array}$} & \multicolumn{2}{|c|}{$\begin{array}{c}\text { Number of isolates } \\
\text { of } C \text {. welchii }\end{array}$} \\
\hline & & & examined & typed \\
\hline $\begin{array}{l}1973 \\
1974 \\
1975^{*} \\
1973-75\end{array}$ & $\begin{array}{r}39 \\
50 \\
64 \\
153\end{array}$ & $\begin{array}{l}21(54 \%) \\
22(44 \%) \\
41(64 \%) \\
84(55 \%)\end{array}$ & $\begin{array}{r}443 \\
739 \\
1037 \\
2219\end{array}$ & $\begin{array}{r}305(69 \%) \\
443(60 \%) \\
700(67 \%) \\
1448(65 \%)\end{array}$ \\
\hline
\end{tabular}

following absorption tests. Cells from 18-h glucose broth cultures of $C$. welchii types 21, 26, 29 and 31 were collected by centrifugation, washed twice, and separately re-suspended in $20-\mathrm{ml}$ volumes of $0.85 \%$ saline. Each suspension was divided into two equal portions A and B. Cells of portion A were heated with an equal volume of $10 \%$ trichloroacetic acid (TCA) in a boiling water bath until no capsules were visible in test samples. The suspension was neutralised with $0 \cdot 1 \mathrm{M}$ sodium hydroxide and the cells were centrifuged and washed twice. Cells of portion B did not receive this TCA treatment. The pelleted cells from each portion were re-suspended in $2 \mathrm{ml}$ of holomogous serum, incubated at $50^{\circ} \mathrm{C}$ for $2 \mathrm{~h}$ and then removed by centrifugation. The resulting serum samples were tested for changes in their homologous titres and heterologous cross-reactions. Antisera were prepared against the acid-treated cells and the respective homologous and heterologous titres were measured.

Loss of strain-specific antigen in naturally rough $C$. welchii. Rough forms of $C$. welchii types 12,26 and 31 were isolated by the selection of colonies with consistently rough characteristics on repeated subculture. Antisera were prepared against these rough strains and serum titres were determined by the indirect fluorescent antibody technique. Tube agglutination tests were also performed with suspensions prepared from the respective smooth cultures.

Approximately equal numbers of the rough and smooth cells of $C$. welchii types 12 and 26 were used separately to absorb the corresponding homologous antisera prepared with the smooth forms, and the titres of the absorbed sera were determined. Preparations of the smooth and rough forms were stained with Indian ink and $1 \%$ carbol fuchsin to determine the presence or absence of capsules.

Reversion of rough forms to smooth. Attempts were made to bring about reversion of a rough form of $C$. welchii (strain no. FH3701/67) to the typical smooth form. Media used included the sporulation medium of Duncan and Strong (1968), Columbia Base Agar (Oxoid) with $5 \%$ horse or sheep blood, tryptone-sulphite-neomycin agar (Marshall, Steenbergen and McClung, 1965) and veal cooked-meat prepared according to Cruickshank (1968) but with boneless veal in place of bullocks' hearts.

Animal-passage experiments were also performed: adult monkeys, mice and newly hatched chicks were fed and suckling mice were given intragastric inoculations of the viable rough cells. Cultures from faeces and intestinal contents of mice and chicks obtained at necropsy were searched for smooth colonial forms. Parenteral inoculations were made in mice; these animals were killed at $24 \mathrm{~h}$ and $48 \mathrm{~h}$ and the viscera cultured. Embryonated eggs 
were given inoculations by the yolk sac route and cultures were made from the dead embryos. Isolates were re-passaged whenever there was an increase in smoothness of colonies.

\section{RESULTS}

\section{Serotypes}

Over the 3-year period 1973-75, 1591 of $2499(64 \%)$ C. welchii type A isolates were successfully serotyped. They were placed in three categories according to source: (1) strains from outbreaks of food poisoning; (2) strains from human infections other than those associated with food poisoning; and (3) strains from the environment, faecal specimens from healthy persons, and foods not associated with outbreaks of food poisoning.

It was possible to serotype 1448 of $2219(65 \%)$ isolates from 153 foodpoisoning outbreaks (table II); in $84(55 \%)$ of the outbreaks, the causative serotype was established by demonstration of a common $C$. welchii serotype in the majority of faecal samples and also in the suspected food when this was available. A predominance of certain serotypes was noted (table III). Nontypable isolates from earlier outbreaks were used to prepare new antisera for expansion of the series. In a number of the outbreaks, faecal sampling or the number of isolates submitted for typing was inadequate; the causative serotypes could not be established with certainty and epidemiological conclusions could not be drawn.

In 15 of the outbreaks, the numbers of $C$. welchii in faecal samples or the implicated food, or both, were determined. The median count of $C$. welchii in 68 faecal specimens from nine of the outbreaks was $2.5 \times 10^{5}$ per $\mathrm{g}$ (range $1 \times 10^{3}$ to $8.5 \times 10^{6}$ per $\mathrm{g}$ ). The median $C$. welchii counts in foods incriminated in 10 of the outbreaks was $4.5 \times 10^{5}$ per $\mathrm{g}$ (range $2 \times 10^{3}$ to $2.5 \times 10^{8}$ per g).

Of 176 isolates from 32 patients in the second category, $104(59 \%)$ could be typed; the potential value of the serotyping system for epidemiological investigations of clinical infections with $C$. welchii was demonstrated. In several of the incidents, however, inadequate numbers of isolates were submitted, so that little epidemiological significance could be attached to the typing results.

A heterogeneous collection of serotypes was found among $39(37.5 \%)$ typable isolates out of 100 in category 3.

\section{Determination of the strain-specific antigen}

The results of absorption tests with capsulate and decapsulated cells of C. welchii types $21,26,29$ and 31 are shown in table IV. The samples of homologous sera absorbed with acid-treated cells showed no loss of titre, but there was a considerable loss when these sera were absorbed with untreated cells. Similar results were obtained with the cross-reacting antigens. There was variation in the natural degree of capsulation of each serotype, designated as,+++ or +++ on the basis of capsule staining, but this variation did not affect the homologous and heterologous titres. 
TABLE III

Distribution of serotypes of Clostridium welchii type A among isolates from 153 incidents of food poisoning, 32 cases of clinical infection and 99 sources not associated with foodpoisoning outbreaks or clinical infections*

\begin{tabular}{|c|c|c|c|c|c|c|c|}
\hline \multirow{4}{*}{ Serotype } & \multicolumn{4}{|c|}{ Number isolated from } & \multirow{2}{*}{\multicolumn{3}{|c|}{$\begin{array}{l}\text { Number not associated with food- } \\
\text { poisoning outbreaks or clinical } \\
\text { infections but isolated from }\end{array}$}} \\
\hline & \multirow{2}{*}{\multicolumn{2}{|c|}{$\begin{array}{l}\text { food- } \\
\text { poisoning } \\
\text { incidents }\end{array}$}} & \multirow{2}{*}{\multicolumn{2}{|c|}{$\begin{array}{l}\text { clinical } \\
\text { infections }\end{array}$}} & & & \\
\hline & & & & & \multirow[t]{2}{*}{ faeces } & \multirow{2}{*}{$\begin{array}{l}\text { foods and } \\
\text { food-working } \\
\text { surfaces }\end{array}$} & \multirow{2}{*}{$\begin{array}{l}\text { hospital } \\
\text { environmen } \\
\text { (floors and } \\
\text { air) }\end{array}$} \\
\hline & $\mathrm{C}$ & $\mathrm{NC}$ & $\mathrm{C}$ & $\mathrm{NC}$ & & & \\
\hline \multirow{35}{*}{$\begin{array}{c}\text { NT } \\
3 / 4 \dagger \\
4 \\
1 \\
41 \\
17 \\
29 \\
7 \\
31 \\
10 \\
25 \\
28 \\
38 \\
55 \\
3 \\
5 \\
11 \\
16 \\
18 \\
23 \\
27 \\
32 \\
33 \\
34 \\
39 \\
9 \\
12,13 \\
20 \\
21 \\
30,35 \\
37 \\
40 \\
41 \\
43 \ddagger \\
44,45,46, \\
49,51,54 \\
50 \\
52,56\end{array}$} & 44 & NR & 14 & NR & 25 & 29 & 7 \\
\hline & $20\}$ & 8 & 0) & 2 & 0 & 0 & 0 \\
\hline & $9\}$ & 0 & $2 j$ & 2 & 0 & 0 & 1 \\
\hline & 9 & 7 & 0 & 0 & 0 & 0 & 0 \\
\hline & 9 & 3 & 0 & 0 & 0 & 0 & 0 \\
\hline & 0 & 7 & 0 & 0 & 8 & 1 & 0 \\
\hline & 6 & 5 & 1 & 0 & 0 & 1 & 0 \\
\hline & 5 & 3 & 0 & 0 & 0 & 0 & 0 \\
\hline & 5 & 9 & 0 & 0 & 0 & 0 & 0 \\
\hline & 3 & 5 & 0 & 0 & 8 & 2 & 0 \\
\hline & 3 & 13 & 3 & 0 & 0 & 0 & 0 \\
\hline & 3 & 3 & 1 & 2 & 0 & 1 & 2 \\
\hline & 3 & 7 & 2 & 1 & 0 & 0 & 0 \\
\hline & 3 & 0 & 0 & 0 & 0 & 0 & 0 \\
\hline & 2 & 2 & 0 & 0 & 0 & 0 & 0 \\
\hline & 2 & 9 & 2 & 0 & 0 & 2 & 0 \\
\hline & 2 & 11 & $\overline{0}$ & 1 & 0 & 0 & 0 \\
\hline & 2 & 0 & 0 & 0 & 0 & 0 & 0 \\
\hline & $\overline{0}$ & 1 & 2 & 1 & 0 & 0 & 0 \\
\hline & 1 & 5 & 0 & 1 & $\stackrel{0}{0}$ & 0 & 2 \\
\hline & 2 & 6 & 0 & 1 & 0 & 1 & 0 \\
\hline & $\overline{2}$ & 1 & 0 & 0 & 0 & 2 & 0 \\
\hline & 5 & 6 & 0 & 2 & 0 & 0 & 0 \\
\hline & 2 & 9 & 2 & 0 & 0 & 0 & 0 \\
\hline & 2 & 4 & 2 & 1 & 0 & 0 & $\stackrel{0}{0}$ \\
\hline & $\begin{array}{l}1 \\
1\end{array}$ & $\begin{array}{l}2 \\
2\end{array}$ & $\begin{array}{l}0 \\
0\end{array}$ & $\begin{array}{l}1 \\
0\end{array}$ & $\begin{array}{l}0 \\
0\end{array}$ & $\begin{array}{l}1 \\
0\end{array}$ & $\begin{array}{l}0 \\
0\end{array}$ \\
\hline & $\begin{array}{l}1 \\
0\end{array}$ & 3 & 1 & 1 & 1 & $\begin{array}{l}0 \\
1\end{array}$ & $\begin{array}{l}0 \\
0\end{array}$ \\
\hline & 1 & 0 & 0 & 0 & 0 & 1 & 0 \\
\hline & 0 & 6 & 0 & 0 & 0 & 1 & 0 \\
\hline & 0 & 1 & 0 & 1 & 0 & 0 & 1 \\
\hline & 0 & 2 & 0 & 0 & 0 & 0 & 1 \\
\hline & 0 & 3 & $\stackrel{0}{0}$ & $\begin{array}{l}0 \\
0\end{array}$ & $\begin{array}{l}0 \\
0\end{array}$ & $\begin{array}{l}0 \\
0\end{array}$ & $\stackrel{0}{0}$ \\
\hline & 1 & 1 & 0 & 0 & 0 & 0 & 0 \\
\hline & 1 & 0 & 0 & 0 & 0 & 0 & 0 \\
\hline & $\begin{array}{l}0 \\
0\end{array}$ & 3 & 0 & 0 & 0 & $\begin{array}{l}0 \\
0\end{array}$ & 0 \\
\hline
\end{tabular}

* $\mathrm{C}=$ causative; $\mathrm{NC}=$ not causative; $\mathrm{NR}=$ not reported; $\mathrm{NT}=$ not typable.

$\dagger=$ Causative isolates were agglutinated by both antisera.

$\ddagger=$ Serotypes nos. 43-56 were added to the scheme in 1975 . 


\section{TABLE IV}

Titres of Clostridium welchii antisera before and after absorption with normal and decapsulated cells

\begin{tabular}{|c|c|c|c|c|c|c|c|}
\hline $\begin{array}{l}\text { Homologous } \\
\text { serotype no. }\end{array}$ & $\begin{array}{l}\text { Degree of } \\
\text { capsulation* }\end{array}$ & $\begin{array}{l}\text { Treatment } \\
\text { of serum } \dagger\end{array}$ & Titre & $\begin{array}{c}\text { Cross- } \\
\text { reacting } \\
\text { serotype } \\
\text { no. }\end{array}$ & $\begin{array}{l}\text { Degree of } \\
\text { capsulation* }\end{array}$ & $\begin{array}{l}\text { Treatment } \\
\text { of cross- } \\
\text { reacting } \\
\text { serum } \dagger\end{array}$ & Titre \\
\hline 21 & ++ & $\left\{\begin{array}{l}\mathrm{A} \\
\mathbf{B} \\
\mathbf{C} \\
\mathrm{A}\end{array}\right.$ & $\begin{array}{r}512 \\
512 \\
4 \\
512\end{array}$ & 18 & ++ & $\left\{\begin{array}{l}\mathrm{A} \\
\mathrm{B} \\
\mathbf{C}\end{array}\right.$ & $\begin{array}{l}4 \\
4 \\
2\end{array}$ \\
\hline 26 & +++ & $\left\{\begin{array}{l}\mathrm{B} \\
\mathrm{C}\end{array}\right.$ & $\begin{array}{r}512 \\
4\end{array}$ & $\ldots$ & $\ldots$ & $\ldots$ & $\cdots$ \\
\hline 29 & +++ & $\left\{\begin{array}{l}\mathrm{A} \\
\mathrm{B} \\
\mathrm{C}\end{array}\right.$ & $\begin{array}{r}128 \\
128 \\
8\end{array}$ & 8 & ++ & $\left\{\begin{array}{l}\mathbf{A} \\
\mathbf{B} \\
\mathbf{C}\end{array}\right.$ & $\begin{array}{r}16 \\
16 \\
8\end{array}$ \\
\hline 31 & + & $\left\{\begin{array}{l}\mathrm{A} \\
\mathrm{B} \\
\mathrm{C}\end{array}\right.$ & $\begin{array}{r}256 \\
256 \\
2\end{array}$ & FH3697/67 & +++ & $\left\{\begin{array}{l}\mathrm{A} \\
\mathrm{B} \\
\mathbf{C}\end{array}\right.$ & $\begin{array}{r}128 \\
128 \\
2\end{array}$ \\
\hline
\end{tabular}

* Degree of capsulation designated as,+++ or +++ according to the result of capsule staining.

$\dagger \mathbf{A}=$ untreated serum; $\mathbf{B}=$ serum absorbed with homologous acid-treated cells; $\mathbf{C}=$ serum absorbed with homologous normal cells.

$\downarrow=$ Serotype not yet assigned a position in the serotyping system.

\section{TABLE V}

Results of tests with antisera produced against rough and acid-treated Clostridium welchii cells of three serotypes

\begin{tabular}{|c|c|c|c|}
\hline \multirow{2}{*}{$\begin{array}{l}\text { Serotype } \\
\text { no. }\end{array}$} & \multirow{2}{*}{$\begin{array}{c}\text { Antigen } \\
\text { preparation* }\end{array}$} & \multicolumn{2}{|c|}{$\begin{array}{l}\text { Agglutinin titre } \\
\text { determined by } \dagger\end{array}$} \\
\hline & & FA & TAS \\
\hline $\begin{array}{l}26 \\
26 \\
29 \\
31 \\
31\end{array}$ & $\begin{array}{l}\text { Rough } \\
\text { Acid-treated } \\
\text { Acid-treated } \\
\text { Rough } \\
\text { Acid-treated }\end{array}$ & $\begin{aligned} & 20 \\
> & 50 \\
> & 50 \\
> & 50 \\
> & 50\end{aligned}$ & $\begin{array}{l}<2 \\
<2 \\
<2 \\
<2 \\
<2\end{array}$ \\
\hline
\end{tabular}

* = No capsules were visible by capsule stain with any of these preparations.

$\dagger \mathrm{FA}=$ serum titre determined by fluorescent-antibody technique; TAS $=$ agglutinin titre determined in tube tests with parent-type smooth cells of corresponding serotype.

Results of experiments with the rough forms of $C$. welchii types 12,26 and 31 are shown in tables V and VI. Little capsular material was demonstrable around rough cells as compared with their smooth counterparts. The rough cells agglutinated in normal saline; no means was found to overcome this effect and serum titres could not be determined by tube agglutination. By fluorescent antibody tests, antisera produced against rough cells of $C$. welchii types 26 and 31, and acid-treated cells of types 26, 29 and 31 were shown to 
TABLE VI

Clostridium welchii antisera absorbed with smooth and rough cells

\begin{tabular}{ccccc}
\hline $\begin{array}{c}\text { Serotype no. } \\
\text { (and S/R state) }\end{array}$ & $\begin{array}{c}\text { Degree of } \\
\text { capsulation } \dagger\end{array}$ & \multicolumn{2}{c}{$\begin{array}{c}\text { Agglutinin titre of } \\
\text { bomologous serum } \ddagger \\
\text { absorption }\end{array}$} & $\begin{array}{r}\text { after } \\
\text { absorption }\end{array}$ \\
\hline 12 & $\mathrm{~S}$ & ++ & 1024 & 64 \\
12 & $\mathrm{R}$ & + & 1024 & 512 \\
26 & $\mathrm{~S}$ & +++ & 256 & 8 \\
26 & $\mathrm{R}$ & - & 256 & 256 \\
\hline
\end{tabular}

$* \mathrm{~S}=$ smooth $; \mathrm{R}=$ rough.

$\dagger=$ Degree of capsulation graded - to +++ according to results of capsule staining.

$\ddagger=$ Agglutination titre determined in tube tests with suspensions of respective smooth cells.

contain homologous antibodies, but tube agglutination tests with the parent smooth forms revealed that the original type-specific and cross-reacting antibodies were not present (table V). Absorption of sera with rough cells of types 12 and 26 did not cause a significant loss of titre as compared with the loss of titre after absorption with the smooth forms (table VI).

Efforts to change a rough strain back to its smooth form were unsuccessful. A slight alteration in appearance of colonies towards the smooth form was obtained in the initial passages through suckling mice and chick embryos, but this did not progress with subsequent passages and the cells remained autoagglutinating. $\alpha$-Toxin (lecithinase) production, detected by the production of opalescence around colonies on egg-yolk agar, was also greatly reduced in some rough forms; this was found to be increased to some extent by passage of rough strains through suckling mice, chicks and chick embroyos. Different media produced slight variations in colony form, but the degree of capsulation and auto-agglutinability in saline remained unaltered. During these studies, it was evident that the use of Oxoid Columbia Base horse-blood agar enhanced growth and gave larger colonies; the medium has now been adopted in this laboratory for the isolation and enumeration of $C$. welchii and for observation of the haemolytic effects of its colonies on blood agar.

\section{Discussion}

The majority of strains of $C$. welchii type A forming the basis of the serotyping system used in these studies were originally isolated from cases of food poisoning; recently, strains from other sources have been included (table I). In practice it has become apparent that it is not justifiable to maintain the previous distinction between heat-resistant and heat-sensitive $C$. welchii isolates and new Arabic numerals have been assigned to heat-sensitive serotypes 
TABLE VII

Revised serotype designations for heat-sensitive Clostridium welchii type $A^{*}$

\begin{tabular}{ll|lr}
\hline \begin{tabular}{cc|} 
Former \\
type no.
\end{tabular} & $\begin{array}{c}\text { New } \\
\text { type no. }\end{array}$ & $\begin{array}{l}\text { Former } \\
\text { type no. }\end{array}$ & $\begin{array}{c}\text { New } \\
\text { type no. }\end{array}$ \\
\cline { 1 - 2 } i, xii & 23 & x & 29 \\
ii & 24 & xi & 39 \\
iii, v & 25 & xiii & 17 \\
iv & E† & xiv & 4 \\
vi & 26 & xv & 9 \\
vii & 38 & xvi & 40 \\
viii & 27 & xvii & 30 \\
ix & 28 & xviii & 31 \\
\hline
\end{tabular}

* See Hobbs et al. (1973).

$\dagger \mathrm{E}=$ eliminated; stock culture not viable.

originally designated by Roman numerals (table VII; Hobbs et al., 1973); serotype numbers have been combined where strong cross-reactions have been found consistently over the period of study.

C. welchii can be confirmed as the causative agent of a food-poisoning outbreak by the demonstration of a common serotype in the majority of faecal samples and, if available, the suspect food. It is necessary to demonstrate this common serotype since typable strains are frequently isolated from the stools of healthy persons or those with diarrhoeal disease from other causes (Sutton, 1969; Akama and Otani, 1970; Sutton et al., 1971; J. A. Hughes, unpublished data) and from the environment.

The results of applying the serotyping scheme to the investigation of 153 food-poisoning outbreaks and 32 cases of gas gangrene or other clinical conditions have clearly demonstrated the value of the scheme in the epidemiological study of food-borne disease and clinical infections caused by $C$. welchii type A.

Since $C$. welchii is usually present in faeces, serological typing in the investigation of food-poisoning outbreaks can be of value only if a sufficient number of isolates from each sample of faeces-and food, if available-is picked for typing. In a quarter of the outbreaks, inadequate numbers of isolates were submitted for typing and the investigations were inconclusive. Outbreaks due to more than one serotype may occasionally be encountered.

Guidelines for investigating food-poisoning outbreaks by means of the serotyping scheme are as follows: (1) details of the outbreak should be noted on a questionnaire form such as that suggested by Hobbs (1969); (2) at least three isolates from each faecal and food sample should be picked for serotyping; and (3) the numbers of $C$. welchii organisms in faecal and food samples should be determined when possible.

Sutton et al. (1971) showed that faeces from persons with $C$. welchii food poisoning contain significantly larger numbers of $C$. welchii than those from healthy persons or patients with diarrhoea due to other causes; it was proposed 
that this constitutes a useful diagnostic criterion for $C$. welchii food poisoning. In the nine outbreaks in which faecal $C$. welchii counts were determined, the median count of $2.5 \times 10^{5}$ per $\mathrm{g}$ was significantly higher than the median and mean faecal counts in healthy persons reported by Sutton et al. (1971) and Hauschild, Hilsheimer and Griffith (1974) respectively.

C. welchii counts in the implicated foods were obtained in 10 of the outbreaks and, in all but two instances, were abnormally high. C. welchii is not infrequently found in foods, but numbers are usually small and enrichment is required for their isolation.

These results demonstrate the value of determining faecal and food counts of $C$. welchii in conjunction with serotyping for epidemiological investigations of food poisoning. Although standard plate-count techniques are the ideal, where shortages of time and manpower exist, useful approximate $C$. welchii counts can be obtained by plating 10-fold dilutions of suspensions of faecal or food samples in physiological saline with disposable calibrated loops (Nunc, Roskilde, Denmark).

In clinical investigations, as in food-poisoning investigations, it is important to submit several isolates from each sampling site or specimen being investigated.

Decapsulated $C$. welchii cells used in absorption experiments did not lower the titres of antisera to the respective parent smooth (capsulate) forms, and type-specific antibodies were not produced in rabbits inoculated with decapsulated cells; these results indicate that the type-specific and cross-reacting antigens reside in the capsular layer, thus supporting the results of Baine and Cherniak (1971), Lee and Cherniak (1974) and Paine and Cherniak (1975). Evidence that development of roughness represents a natural loss of the capsule, and hence loss of the type-specific antigen, is also given. Development of roughness is most frequently associated with passage on artificial media or with prolonged storage of the organism but, on rare occasions, rough forms are encountered in the field; these cannot be typed or used for preparation of type-specific antisera.

Attempts to transform a rough strain to the smooth form were unsuccessful but the indications were that occasional passage of stock strains through suckling mice, chicks or chick embryos might help to prevent loss of capsule and development of roughness.

Serotyping schemes for $C$. welchii type A have been developed independently in America and Japan as well as in Britain. Co-operative work is in progress to combine the three schemes in order to develop internationally acceptable serotyping facilities for $C$. welchii type A and a separate report is expected in the near future.

\section{SUMMARY}

A serotyping scheme for Clostridium welchii (C. perfringens) type A employing 57 antisera has been used to investigate the epidemiology of 153 foodpoisoning outbreaks and 32 cases of gas gangrene and other clinical infections. Respectively $65 \%$ and $59 \%$ of the isolates were typable, and in $55 \%$ of the 
food-poisoning outbreaks the causative serotypes were established. Isolation and reporting methods that would render the typing scheme of even greater epidemiological value are described.

The type-specific antigen was shown to reside in the capsule and to be lost from strains that had become rough. Development of roughness and its prevention are described.

A great range of antisera and an internationally acceptable serotyping scheme is expected after integration of this set with those developed independently in America and Japan.

The authors are grateful to many directors of public health laboratories and hospital consultant bacteriologists for sending the cultures that have made this study possible, and are indebted to Dr Betty C. Hobbs for advice and encouragement.

\section{REFERENCES}

AKAMA, K. AND OTANI, S. 1970. Clostridium perfringens as the flora in the intestine of healthy persons. Jap. J. med. Sci. Biol., 23, 161.

Baine, H. AND CherniaK, R. 1971. Capsular polysaccharides of Clostridium perfringens Hobbs 5. Biochemistry, N.Y., 10, 2948.

Cruickshank, R., Duguid, J. P. and Swain, R. H. A. 1968. In Medical microbiology, 11 th ed., London and Edinburgh, p. 775.

DunCAN, C. L. AND STRONG, D. H. 1968. Improved medium for sporulation of Clostridium perfringens. Appl. Microbiol., 16, 82.

Hall, H. D., Angelotti, R., Lewis, K. H. and Foter, M. J. 1963. Characteristics of Clostridium perfringens strains associated with food and food-borne disease. J. Bact., 85, 1094.

Hauschild, A. H. W., Hilsheimer, R. AND Griffith, D. W. 1974. Enumeration of fecal Clostridium perfringens spores in egg yolk-free tryptose-sulfite-cycloserine agar. Appl. Microbiol., 27, 527.

HENDERSON, D. W. 1940. The somatic antigens of the Clostridium welchii group of organisms. J. Hyg. Camb., 40, 501.

HoвBs, B. C. 1969. Clostridium perfringens and Bacillus cereus infections. In Food-borne infections and intoxications, edited by H. Riemann, New York and London, p. 131.

Hobrs, B. C., Clifford, W., Ghosh, A. C., Gilbert, R. J., Kendall, M., Roberts, D. ANd WIENEKE, A. A. 1973. Sampling of food and other material for bacteriological and ecological studies. In Sampling-microbiological monitoring of environments (Soc. appl. Bact. Tech. Ser. No. 7), edited by R. G. Board and D. W. Lovelock, London, p. 233.

Hobrs, B. C., Smith, M. E., OAKley, C. L., Warrack, G. H. and Cruickshank, J. C. 1953. Clostridium welchii food poisoning. J. Hyg., Camb., 51, 75.

LEE, L. AND ChERNIAK, R. 1974. Capsular polysaccharide of Clostridium perfringens Hobbs 10. Infect. Immun., 9, 318.

McClung, L. S. ANd Toabe, R. 1947. The egg yolk plate reaction for the presumptive diagnosis of Clostridium sporogenes and certain species of the gangrene and botulinum groups. J. Bact., 53, 139.

Marshall, R. S., Steenbergen, J. F. ANd McClung, L. S. 1965. Rapid technique for the enumeration of Clostridium perfringens. Appl. Microbiol., 13, 559.

Paine, C. M. AND Cherniak, R. 1975. Composition of the capsular polysaccharides of Clostridium perfringens as a basis for their classification by chemotypes. Can.J. Microbiol., 21181.

Surron, R. G. A., 1969. ' The pathogenesis and epidemiology of Clostridium welchii food poisoning. Ph.D. Thesis, University of London. 
Sutton, R. G. A., Ghosh, A. C. ANd HobBs, B. C. 1971. Isolation and enumeration of Clostridium welchii from food and faeces. In Isolation of anaerobes (Soc. appl. Bact. Tech. Ser. No. 5), edited by D. A. Shapton and R. G. Board, London, p. 39.

Sutton, R. G. A. AND HobBs, B. C. 1968 . Food poisoning caused by heat-sensitive Clostridium welchii. A report of five recent outbreaks. J. Hyg., Camb., 66, 135.

TAylor, C. E. D. AND CoETzeE, E. F. C. 1966. Range of heat resistance of Clostridium welchii associated with suspected food poisoning. Mon. Bull. Minist. Hlth. Lab. Serv., 25, 142.

Vernon, E. AND Tillett, H. E. 1974. Food poisoning and salmonella infections in England and Wales, 1969-1972. Publ. Hlth, Lond., 88, 225. 